\title{
Pengaruh Ketebalan Bahan dan Jumlah Desikan terhadap Laju Pengeringan Jahe (Zingiber officinale Roscoe) pada Pengering Kombinasi Surya dan Desikan
}

\section{Effect of Material Thickness and Amount of Desiccant on Drying Rate of Ginger (Zingiber officinale Roscoe) at Solar Dryer Integrated with Desiccant}

\author{
Muhammad Alfikri Ridhatullah*, Rosdanelli Hasibuan \\ Departemen Teknik Kimia, Fakultas Teknik, Universitas Sumatera Utara \\ Jl. Almamater Kampus USU, Medan, 20155, Indonesia \\ *Email: alfikridh@gmail.com
}

\begin{abstract}
Abstrak
Jahe merupakan tanaman rempah yang biasa dimanfaatkan sebagai bumbu masakan atau bahan baku obat, tradisional atau industri. Jahe memiliki kandungan air yang tinggi sehingga mudah terkontaminasi mikroba dan bahan aktif (gingerol) yang mudah rusak akibat suhu tinggi. Pengeringan jahe bertujuan untuk menjaga kualitas jahe kering tetap terjaga dan bebas dari mikroba. Proses pengeringan jahe dilakukan secara berkelanjutan dengan pengering surya meggunakan kolektor plat datar pada saat siang dan dilanjutkan desikan Molecular Sieve X13 ketika malam. Pengeringan memvariasikan ketebalan jahe $2 \mathrm{~mm}, 4 \mathrm{~mm}$, dan $6 \mathrm{~mm}$, serta perbandingan jumlah bahan dan desikan 1:1;1:2; dan 1:3. Untuk mendapatkan data karakteristik pengeringan, neraca elektrik digunakan menghitung massa setiap 1 jam sekali dan data logger tiap 5 menit menghitung suhu dan kelembaban pada ruang pengering. Hasil dari pengeringan jahe didapat bahwa ketebalan $6 \mathrm{~mm}$ membutuhkan waktu lebih dari 20 jam proses pengeringan sehingga membutuhkan pengeringan kombinasi dibandingkan ketebalan lain, dan dari hasil analisa kualitas jahe kering, parameter kadar abu sesuai standar SNI, dan perbandingan bahan dan desikan 1:1 merupakan variasi yang paling mendekati standar SNI.
\end{abstract}

Kata kunci: jahe, kombinasi pengeringan surya dan desikan, ketebalan bahan, perbandingan jumlah desikan

\begin{abstract}
Ginger is a spice plant that is usually used as a seasoning in cooking or raw material for medicine, traditional or industrial medicine. Ginger has a high-water content so its easily contaminated with microbes and has active ingredients (gingerol) which are easily damaged by high temperatures. Ginger drying is intended for maintaining the quality of dry ginger and keep ginger from microbes. The drying process has done in continuously with solar dryer using flat plate type collector during the day and at night using the Molecular Sieve 13x desiccant. Drying varies the thickness of ginger $2 \mathrm{~mm}, 4 \mathrm{~mm}$, and $6 \mathrm{~mm}$, and the amount ratio of desiccant: 1:1;1:2; and 1:3. To get drying characteristics, every 1-hour mass calculated using an electric scale, and data logger every 5 minutes calculates the temperature and humidity rate $(\mathrm{RH})$ in the drying chamber. The result from ginger drying is the thickness of $6 \mathrm{~mm}$ needed more than 20 hours of drying process so that it needed the combination of dryer compared to other thickness, and from quality analysis results of dry ginger, ash content parameters already accordance with SNI standards, and 1:1 material and desiccant ratio is the variation that most closely matches the SNI standard.
\end{abstract}

Keyword: ginger, combination of solar and desiccant dryer, material thickness, desiccant amount ratio

\section{Pendahuluan}

Jahe merupakan tanaman rempah yang penting bagi dunia yang biasa dimanfaatkan dalam keadaan segar atau kering. Jahe merupakan tanaman wilayah tropis, seperti Indonesia. Jahe memiliki manfaat seperti rempah-rempah dan sebagai obat serta beragam aplikasi industri. Jahe terdiri dari karbohidrat, protein, pati, serat rimpang dan juga terdapat oleoresin sebagai minyak esensial dengan bau menyengat [6].
Pengeringan jahe bertujuan untuk pengawetan agar jahe tetap berkualitas baik dengan kandungan air yang seragam dan agar tidak mudah terkontaminasi mikroba. Pengeringan secara umum bertujuan untuk proses pengawetan bahan, hal itu dilakukan untuk menjaga kualitas jahe tetap terjaga ketika proses ekspor, proses pengeringan memanfaatkan energi matahari untuk mengurangi kandungan air pada bahan [2, 4]. 
Indonesia memiliki potensi energi surya sebagai energi alternatif yang bisa digunakan sebagai sumber energi pada proses pengeringan. Namun pengeringan menggunakan energi surya memiliki kekurangan, dimana energi surya bersifat intermitten (tidak kontinu) dan bergantung pada kondisi cuaca, lalu pada waktu malam hari proses pengeringan tidak dapat dilaksanakan dikarenakan suhu lingkungan menurun dan RH (rasio humiditas) meningkat. Oleh karena itu diperlukan satu solusi agar proses pengeringan tetap berlanjut/kontinu pada malam hari, yaitu dengan mengkombinasikan proses pengeringan surya pada siang hari dan menggunakan desikan pada malam hari $[11,13]$.

Atas dasar pemikiran yang telah dipaparkan diatas, maka peneliti ingin melakukan kajian pengaruh variasi ketebalan bahan dan jumlah desikan terhadap laju pengeringan jahe menggunakan pengering kombinasi surya dan desikan (solar assisted molecular sieve dryer).

\section{Teori}

Pengeringan zat padat adalah pemisahan sejumlah kecil air atau zat cair dari bahan sehingga mengurangi kandungan sisa zat cair di dalam zat padat itu sampai suatu nilai rendah yang dapat diterima. Proses pengeringan pada prinsipnya menyangkut proses pindah panas dan pindah massa yang terjadi secara bersamaan. Pertama - tama panas harus ditransfer dari medium pemanas ke bahan. Selanjutnya setelah terjadi penguapan air, uap air yang terbentuk harus dipindahkan melalui struktur bahan ke medium sekitarnya $[7,10]$.

Pengeringan surya dapat dilakukan dengan 3 metode yaitu: 1. Pengeringan terbuka (Open), pengeringan bahan baku langsung dibawah sinar matahari; 2. Alat pengering langsung (Direct), alat pengering surya langsung, memanfaatkan wadah yang dilengkapi dengan penutup diatasnya untuk mengurangi kerugian yang dialami seperti pengeringan terbuka; dan 3. Alat pengering tidak langsung (Indirect), memanfaatkan kolektor sinar surya untuk mengumpulkan panas pada kolektor agar sinar matahari tidak langsung menyinari bahan yang akan dikeringkan. Ketiga metode tersebut dibedakan berdasarkan cara pengumpulan energi matahari dan cara mengkonversi energi tersebut menjadi energi panas [3].

Desikan adalah zat atau bahan yang memproduksi udara kering dikarenakan bahan desikan menyerap kelembaban udara lingkungan. Pengeringan pada suhu dan kelembaban rendah agar kandungan gingerol pada jahe yang sensitif panas tetap terjaga merupakan kelebihan dari pengeringan menggunakan desikan. Prinsip pengeringan menggunakan desikan berdasarkan perpindahan udara lembab (moisture) berdasarkan perbedaan tekanan udara (vapor pressure) antara desikan dan udara lingkungan, desikan dengan moisture content rendah akan menyerap kelembaban udara sampai tekanan udara mencapai kesetimbangan dengan udara sekitar $[1,5]$.

Faktor-faktor yang mempengaruhi pengeringan ada dua golongan yaitu faktor yang berhubungan dengan udara pengering dan faktor yang berhubungan dengan sifat bahan yang dikeringkan. Faktor-faktor yang berhubungan dengan udara pengering adalah suhu, kecepatan, aliran udara pengering dan kelembaban udara. Faktor-faktor yang berhubungan dengan sifat bahan yang dikeringkan adalah ukuran bahan, kadar air awal dan tekanan parsial di dalam bahan [15].

Jahe (Zingiber officinale Roscoe) mempunyai kegunaan yang cukup beragam, antara lain sebagai rempah, minyak atsiri, pemberi aroma, ataupun sebagai obat. Komponen utama dari jahe segar adalah senyawa homolog fenolik keton yang dikenal sebagai gingerol. Gingerol sangat tidak stabil dengan adanya panas dan pada suhu tinggi akan berubah menjadi shogaol. Shogaol lebih pedas dibandingkan gingerol, merupakan komponen utama jahe kering. Jahe kering mempunyai kadar air $7-12 \%$, minyak atsiri $1-3 \%$, oleoresin $5-10 \%$, pati 50-55\% dan sejumlah kecil protein, serat, lemak sampai 7\% [8].

\section{Metodologi Penelitian}

Penelitian ini dilakukan di Laboratorium Energi Baru/Terbarukan Balai Riset dan Standarisasi Industri Medan yang terletak di Jalan Sisingamangaraja, Medan selama 3 bulan.

Bahan yang digunakan pada penelitian ini adalah rimpang dari jahe (Zingiber officinale Roscoe) sebanyak 500 gram dan desikan Molecular sieve $13 \mathrm{X} \quad\left(\mathrm{Na}_{2} \mathrm{O} \cdot \mathrm{Al}_{2} \mathrm{O}_{3} . \quad 2,45\right.$ $\mathrm{SiO}_{2} \cdot 6 \mathrm{H}_{2} \mathrm{O}$ ).

Alat yang digunakan pada penelitian pengering surya (Gambar 1) terdiri dari dua komponen utama: ruang pengering dan kolektor surya. Ruang pengering berdimensi $50 \mathrm{~cm}$ x 50 $\mathrm{cm}$ x $50 \mathrm{~cm}$ dan dilengkapi dengan cerobong, kipas, dan rak untuk meletakkan bahan dan desikan.. Kolektor surya adalah jenis plat datar bersirip dengan dimensi $2 \mathrm{~m} \times 0,5 \mathrm{~m} \times 0,1 \mathrm{~m}$ dengan cover kaca penutup lalu dilapis dengan isolator yang terdiri dari rockwoll, styrofoam dan kayu triplek. Kolektor surya berorientasi ke utara dengan sudut kemiringan $60^{\circ}$. 


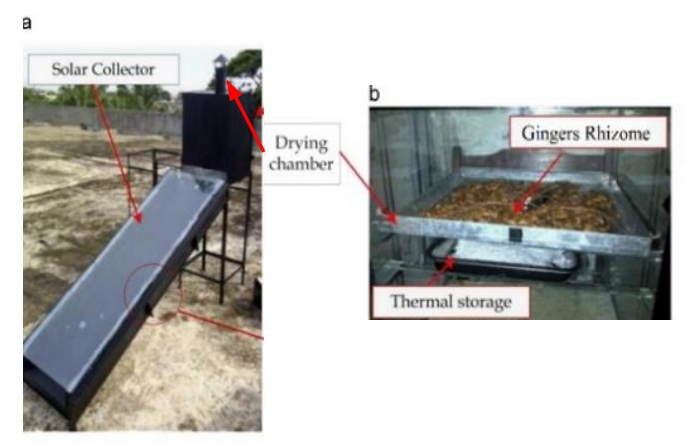

Gambar 1. (a) Alat Pengering, (b) Rak Pengering

Pengambilan data selama penelitian menggunakan $T$ and $R H$ smart sensor data logger, untuk mengukur temperature dan kelembaban udara, dan neraca elektrik, untuk mendapatkan berat bahan per jam.

Prosedur yang dilakukan pada penelitian dimulai dari menimbang jahe sebanyak $0,5 \mathrm{~kg}$ dengan variasi ketebalan $(2 \mathrm{~mm}, 4 \mathrm{~mm}$, dan 6 $\mathrm{mm})$, mempersiapkan data logger yang sudah diatur di laptop untuk merekam data setiap 5 menit sekali, dan kemudian diletakan pada ruang pengering, mengatur kipas pada ruang pengering pada kecepatan 1,1 m/detik [16], penelitian dilakukan pada siang hari (09.0017.00 WIB) dan pada saat malam hari (21.0005.00 WIB menggunakan desikan molecular sieve $13 \mathrm{X} \quad\left(\mathrm{Na}_{2} \mathrm{O} \cdot \mathrm{Al}_{2} \mathrm{O}_{3} . \quad 2,45 \quad \mathrm{SiO}_{2} \cdot 6 \mathrm{H}_{2} \mathrm{O}\right)$ dengan variasi perbandingan jumlah bahan dan desikan $(1: 1 ; 1: 2 ;$, dan 1:3). Pengeringan berjalan dari siang hingga malam dan berulang sampai rimpang jahe mencapai kadar air minimum. Untuk setiap jamnya, bahan dikeluarkan dan ditimbang dengan neraca elektrik, lalu data yang diperoleh lalu digunakan pada perhitungan dan didapat karakteristik pengeringan.

Data yang didapat dari perubahan massa pada penelitian kemudian digunakan untuk mengukur moisture content (basis kering) dengan menggunakan persamaaan 1 [15].

$$
\mathrm{M}_{\mathrm{c}}=\frac{\text { Berat Awal }- \text { Berat Akhir }}{\text { Berat Akhir }} \times 100 \% \ldots \ldots .
$$

Kemudian data moisture content yang didapat diselesaikan untuk menghitung laju pengeringan dengan menggunakan persamaan 2 [5].

$$
\frac{\mathrm{dM}_{\mathrm{c}}}{\mathrm{dt}}=\frac{\text { Berat }_{\mathrm{awal}}-\text { Berat }_{\mathrm{t}}}{\text { waktu }_{\mathrm{t}}-\text { waktu }_{\mathrm{awal}}}
$$

Setelah data laju pengeringan diperoleh, dibuat analisa dari grafik hubungan moisture content vs waktu, laju pengeringan vs waktu, dan laju pengeringan vs moisture content (karakteristik pengeringan).

\section{Hasil \\ Hubungan Moisture Content terhadap Waktu pada Pengeringan Kombinasi Surya - Desikan}

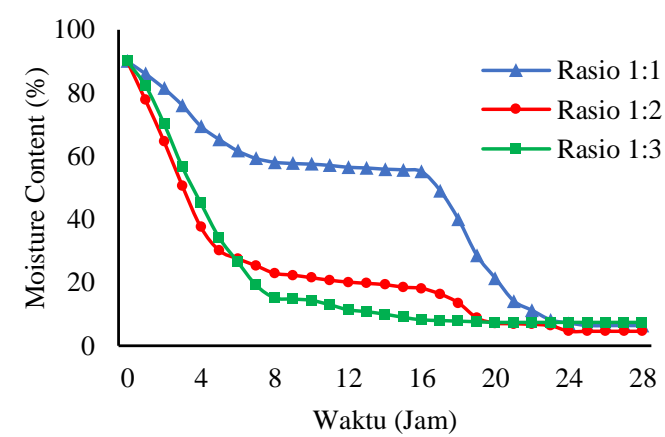

Gambar 2. Hubungan Penurunan Moisture Content terhadap Waktu pada Ketebalan 6 mm

Proses pengeringan hari pertama menunjukan penurunan kadar air relatif cepat dan dalam jumlah yang besar hal ini disebabkan air yang menguap adalah air bebas yang terdapat dipermukaan bahan [9]. Kemudian pada malam hari penurunan kadar air masih terjadi namun walau tidak relatif cepat karena penurunan berat bahan pada malam hari tidak signifikan dibandingkan dengan siang hari. Dan pada hari kedua penurunan kadar air perlahan - lahan menurun hingga mencapai kadar air keseimbanganya. Dalam proses pengeringan, semakin lama bahan dikeringkan, maka kadar air dalam bahan akan semakin berkurang, sampai suatu batas keseimbangan kebasahan bahan tersebut [8].

Proses pengeringan jahe menggunakan kombinasi alat pengering surya dan desikan untuk mencapai kadar kesetimbang mencapai waktu pengeringan yang berbeda. Pada ketebalan jahe sebesar $2 \mathrm{~mm}$ dan $4 \mathrm{~mm}$, rimpang jahe mencapai kadar kesetimbangan dalam waktu kurang dari 12 jam, sehingga hanya pengering surya yang memiliki pengaruh untuk mengeringkan jahe hingga kadar air minimum, dan pada ketebalan jahe $6 \mathrm{~mm}$, waktu yang diperlukan untuk mencapai kadar kesetimbangan adalah lebih dari 20 jam, sehingga diperlukan kombinasi pengering surya dan desikan untuk mengeringkan jahe hingga kadar air minimum. Kadar air rimpang jahe minimum yang didapat pada ketebalan $6 \mathrm{~mm}$ dengan perbandingan bahan dan desikan 1:1; 1:2; dan 1:3 secara berturut adalah $38,3 \%$, $30,5 \%$, dan $41,8 \%$. 
Laju Pengeringan Jahe terhadap Waktu pada Pengeringan Kombinasi Surya Desikan

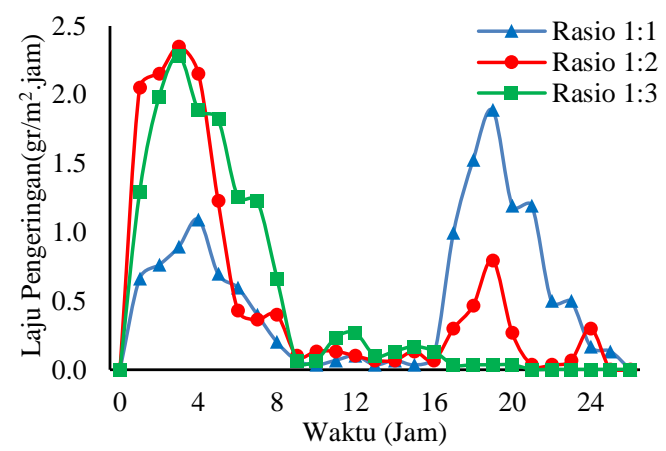

Gambar 3. Hubungan Perbandingan Jumlah Bahan dan Desikan Terhadap Laju Pengeringan pada Ketebalan 6 mm

Gambar 3 menunjukan bahwa laju pengeringan pada periode siang mengalami peningkatan di awal lalu mengalami penurunan terhadap waktu. Laju pengeringan yang menurun menjelaskan bahwa air dalam bahan masih berpotensi untuk mengalami penguapan selama periode akhir pengeringan, hal tersebut terjadi sebab selama prose pengeringan, selain adanya air bebas yang cenderung lebih mudah menguap selama periode awal pengeringan, ada pula air terikat yaitu air yang sulit untuk bergerak naik ker permukaan bahan selama pengeringan sehingga laju penguapan air semakin lama semakin menurun [9].

Pada periode malam, laju pengeringan tidak terlalu meningkat dikarenakan humiditas lingkungan tinggi dan suhu lingkungan yang rendah. Faktor-faktor yang mempengaruhi laju pengeringan terdapat dua faktor, yaitu faktor internal seperti bentuk atau ukuran bahan, dan faktor eksternal seperti suhu, humiditas, kecepatan udara, dan arah udara [16].

Waktu yang dibutuhkan untuk mencapai laju pengeringan konstan untuk masing-masing sampel dengan perbandingan jumlah desikan $1: 1,1: 2$, dan $1: 3$ pada ketebalan $6 \mathrm{~mm}$ adalah 25 jam, 24 jam, dan 20 jam.

Karakteristik Pengeringan Jahe pada Pengeringan Kombinasi Surya - Desikan

Pada Gambar 4 terlihat bahwa kurva periode laju pengeringan mengalami fluktuasi hingga di awal lalu meningkat menuju puncak dari kurva (laju pengeringan maksimum). Pada laju pengeringan maksimum, periode laju pengeringan konstan seharusnya dapat terlihat, karena pada tahap ini permukaan bahan akan selalu basah, sehingga laju pengeringan akan konstan, dimana periode konstan terjadi bila air pada permukaan adalah air jenuh, lalu kondisi operasi pengeringan seperti suhu, humiditas dan kecepatan udara adalah konstan, dan konveksi menuju permukaan bahan hanya dari udara kering [16].

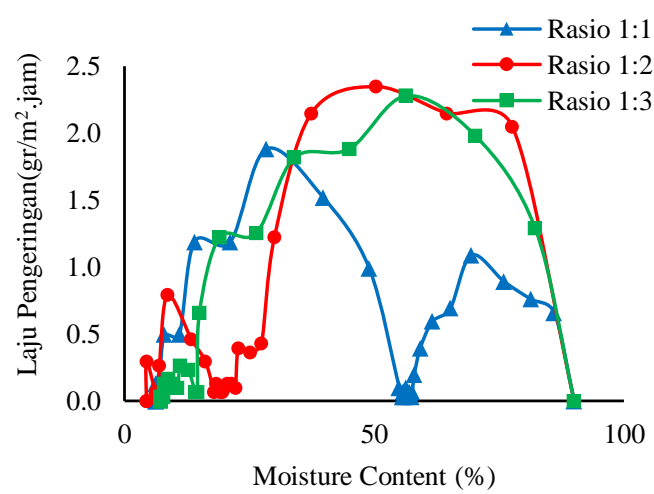

Gambar 4. Hubungan Laju Pengeringan terhadap Moisture Content pada Ketebalan 6 mm

Proses pengeringan terdiri dari 3 periode, yaitu periode naik dimana laju pengeringan meningkat seiring berkurang nya air pada bahan, periode konstan dimana laju air yang berdifusi ke permukaan sebanding dengan air yang menguap pada permukaan bahan, dan periode menurun dimana laju air yang berdifusi ke permukaan lebih kecil dari pada jumlah air yang menguap [16]. Kurva karakteristik dari pengeringan jahe menggunakan kombinasi pengering surya dan desikan dengan variasi ketebalan dan perbandingan bahan-desikan sudah sesuai dengan teori dimana terdapat dua periode pengeringan yaitu periode laju pengeringan meningkat dan periode laju pengeringan menurun. Periode laju pengeringan konstan tidak terlihat pada kurva ini.

\section{Analisa Kualitas Rimpang Jahe Kering}

Rimpang jahe kering yang didapat dari hasil penelitian pengeringan jahe menggunakan kombinasi pengering surya dan desikan dianalisa di Badan Riset dan Standarisasi Nasional (BARISTAN) Medan, Sumatera Utara dan dilakukan sesuai standar nasional (SNI 013393-1994).

Terdapat tiga parameter hasil analisa kualitas jahe kering, yaitu kadar air, kadar abu, dan kandungan minyak. Kandungan minyak jahe menjadi faktor penting pada hasil analisa kualitas jahe kering, karena terdapat gingerol yang memiliki banyak manfaat [8]. 


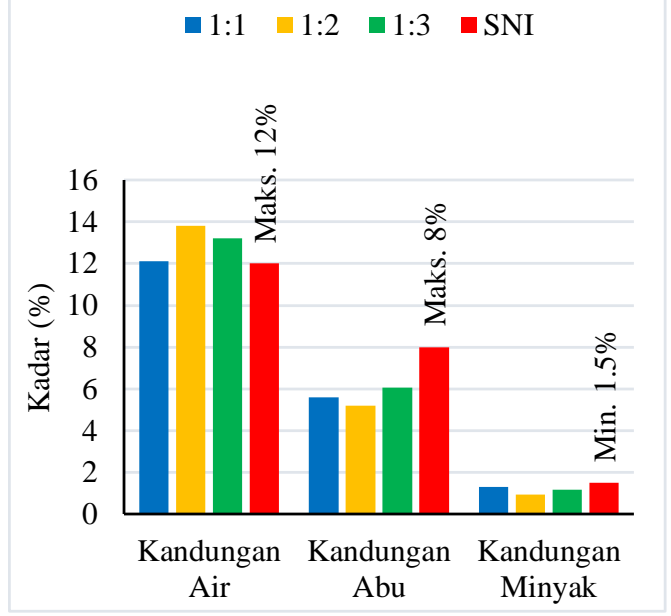

Gambar 5. Hasil Analisa Jahe Kering Menggunakan Kombinasi Pengering Surya dan Desikan pada berbagai perbandingan Bahan dan Desikan (Basis $500 \mathrm{~g}$ )

Gambar 5 menunjukkan tiga parameter hasil analisa kualitas jahe kering pada ketebalan $6 \mathrm{~mm}$ dibandingkan dengan baku mutu (SNI 013393-1994). Dari hasil analisa kadar air yang didapat dari jahe kering pada perbandingan bahan dan desikan $1: 1 ; 1: 2$; dan $1: 3$ adalah $12,1 \%, 13,8 \%$, dan $13,2 \%$, dimana kadar air maksimum pada standar SNI adalah $12 \%$. Hasil analisa hasil kadar abu dari jahe kering pada perbandingan bahan dan desikan $1: 1 ; 1: 2$; dan $1: 3$ adalah $5,6 \%, 5,21 \%$, dan $6,07 \%$, dimana kadar abu maksimum pada standar SNI adalah 8\%. Dan analisa hasil kadar minyak dari jahe kering pada perbandingan bahan dan desikan $1: 1 ; 1: 2$; dan $1: 3$ adalah $1,3 \%, 0,93 \%$, dan $1,18 \%$, dimana kadar minyak minimum pada standar SNI adalah 1,5\%. Dari perbandingan hasil analisa kualitas jahe kering dengan standar SNI, didapat bahwa hasil pengeringan hanya memenuhi standar kualitas parameter kadar abu, sedangkan untuk parameter kadar air dan minyak, jahe kering hasil penelitian belum memenuhi standar, dan perbandingan bahan dan desikan 1:1 dengan ketebalan 6 mm merupakan variasi jahe kering hasil penelitian yang paling mendekati standar SNI.

\section{Kesimpulan}

Kesimpulan yang diperoleh dari penelitian ini adalah:

1. Ketebalan $6 \mathrm{~mm}$ memerlukan waktu lebih dari 20 jam untuk mencapai kadar kesetimbangan sehingga membutuhkan pengeringan dengan kombinasi pengering surya dan desikan, sedangkan untuk ketebalan lebih kecil dari $6 \mathrm{~mm}$, hanya diperlukan pengeringan surya untuk mencapai kadar kesetimbangan.

2. Penggunaan desikan dengan perbandingan 1:3 memiliki pengaruh paling besar dalam proses pengeringan jahe dengan ketebalan 6 $\mathrm{mm}$ pada pengering kombinasi surya dan desikan.

3. Karakteristik pengeringan yang terjadi pada hasil penelitan adalah periode naik dimana laju pengeringan meningkat seiring berkurang nya air pada bahan dan periode turun dimana laju air yang berdifusi ke permukaan lebih kecil dari pada jumlah air yang menguap, sedangkan laju pengeringan konstan tidak terlihat pada karakteristik pengeringan jahe menggunakan kombinasi pengering surya dan desikan.

4. Hasil analisa kualitas jahe pada parameter kadar abu sudah sesuai standar SNI dan rimpang jahe kering pada ketebalan $6 \mathrm{~mm}$ dengan perbandingan bahan dan desikan 1:1 merupakan variasi yang paling mendekati standar SNI.

\section{Daftar Pustaka}

[1] A. A. Pesaran, A Review of Desiccant Dehumidification Technology. National Renewable Energy Laboratory, 1617 Cole Boulevard. Golden, Colorado, Proceeding of Electric Dehumidification: Energy Efficien Humidity Control for Commercial and Institutional Building Conference, (1993) 1-8.

[2] A. S. Mujumdar, S. V. Jangam, C. L. Law, Drying of Foods, Vegetables, and Fruits 1(1), (2006) 1-31.

[3] A. Sharma, C.R. Chen, N. V. Lan, SolarEnergy Drying System: A Review, Renewable and Sustainable Energy Reviews, 13 (2009) 1185-1210.

[4] A. W. Deshmukh, M. N. Varma, C. K Yoo, K. L. Wasewar, Investigation of Solar Drying of Ginger (Zingiber officinale Rosc.): Emprical Modelling, Drying Characteristics, and Quality Study, Chinese Journal of Engineering, (2014) 17.

[5] H. Darvishi, A. R. Asl, A. Asghari, G. Najafi, dan H. A. Gazori, Mathematical Modeling, Moisture Diffusion, Energy consumption and Efficiency of Thin Layer Drying of Potato Slices, Journal of Food Process Technology, 4(3), (2013) 1-6.

[6] H. Rahman, R Karuppaiyan, K. Kishore and R. Denzongpa, Traditional Practices of Ginger Cultivation in North India, Indian Journal of Traditional Knowledge, ICAR 
Research Complex for NEH Region, 8 (2009) 23-28.

[7] H. Vistanty, Pengeringan Pasta Susu Kedelai Menggunakan Pengering Unggun Terfluidakan Partikel Inert, Tesis, Teknik Kimia. $\quad$ Semarang: Universitas Diponegoro, 2010.

[8] Hernani, C. Winarti, Kandungan Bahan Aktif Jahe dan Pemanfaatannya dalam Bidang Kesehatan, JAHE (Zingiber officinale Rosc.), Badan Penelitian dan Pengembangan Pertanian Pusat Penelitian Tanaman Obat dan Aromatik, BALITRO Litbang Deptan, ISBN 978-979-548-0310. (2011) 125-142.

[9] N. Humair, Kesesuaian Model Pengeringan Lapisan Tipis Kunyit (Curcuma domestica Val), Skripsi, Program Studi Keteknikan Pertanian Jurusan Teknologi Pertanian, Makassar: Universitas Hasanuddin, (2014).

[10] O. Rachmawan, Pengeringan, Pendinginan dan Pengemasan Komoditas Pertanian, Modul Dasar Bidang Keahlian, Proyek Pengembangan Sistem dan Standar Pengelolaan SMK, Direktorat Pendidikan Menengah Kejuruan Jakarta, Departemen Pendidikan Nasional, (2001) 1-46.

[11] R. Hasibuan, Karakteristik Alat Pengering Kombinasi Energi Surya dan Tapis Molekular, Laporan Penelitian Dikti, 2009, 1-8.

[12] R. Hasibuan, M. A. Zamzami. The Effect of Operating Conditions on Drying Characteristics and Quality of Ginger (Zingiber officinale Roscoe) Using Combination of Solar Energy-Molecular Sieve Drying System, The 1st Annual Applied Science and Engineering Conference (AASEC) Bandung, (2016) 17.

[13] S. F. Dina, H. Ambarita, F. H. Napitupulu, H. Kawai, Study on Effectiveness of Continuous Solar Dryer Integrated with Desiccant Thermal Storage for Drying Cocoa Beans, Case Studies in Thermal Engineering, 5, (2015) 32-40.

[14] S. Misha, S. Mat, M. H. Ruslan, E. Salleh, K. Sopian, Review of solid/liquid desiccant in the drying applications and its regeneration methods, Renew. Sustain. Energy Rev. 16 (7), (2012), 4686-4707.

[15] Supriyono, Mengukur Faktor-Faktor dalam Proses Pengeringan, Departemen Pendidikan Nasional, Direktorat Jenderal Pendidikan Dasar dan Menengah, Bagian Pengembangan Kurikulum, (2003) 1-39.
[16] Z. Berk, Food Process Engineering and Technology, Departement of Biotechnology and Food Engineering. Israel Institute of Technology 3(22), (2018) 511-521. 